\title{
Differential growth of larval sprat Sprattus sprattus across a tidal front in the eastern North Sea
}

\author{
Peter Munk \\ Danish Institute for Fisheries and Marine Research, Charlottenlund Castle, DK-2920 Charlottenlund, Denmark
}

\begin{abstract}
Spatial variations in abundance and growth of larval sprat Sprattus sprattus L. were examined across a tidal front in the eastern North Sea, off the west coast of Denmark. The aim of the study was to evaluate the potential advantage for sprat larvae of residing in the vicinity of a tidal front. The hydrographic front in the area followed the 20 to $30 \mathrm{~m}$ depth contour and separated a mixed water regime to the east and a stratified regime to the west. Primary production and phytoplankton abundance were highest in the mixed water (>2000 $\mathrm{mg} \mathrm{C} \mathrm{m}^{-2} \mathrm{~d}^{-1}$ and $150 \mathrm{mg}$ chlorophyll $\mathrm{m}^{-2}$ respectively) and declined of fshore towards stratified water. Zooplankton biomass peaked in the central parts of the investigated area in the vicinity of the front (up to $43 \mathrm{mg}$ dry weight $\mathrm{m}^{-3}$ ). Peak densities of sprat larvae $\left(>2 \mathrm{~m}^{-2}\right)$ were found in the front, in a water column stability range from 5 to $30 \mathrm{~J} \mathrm{~m}^{-3}$. The length distributions of larval sprat were dominated by modes of 12 and $16 \mathrm{~mm}$, and growth rates of these 2 size classes were estimated from a Laird-Gompertz curve of larval size at age. Size at age of larvae was estimated by analysis of sagittal otoliths. Growth rate estimates were highest in the mixed water (absolute growth of $12 \mathrm{~mm}$ larva: $0.47 \mathrm{~mm} \mathrm{~d}^{-1}$; weight-specific growth: $0.16 \mathrm{~d}^{-1}$ ). At the mixed side of the front, where larval abundance peaked, growth was slightly lower, whereas growth rate declined significantly further offshore (to a minimum for $16 \mathrm{~mm}$ larva of $0.13 \mathrm{~mm} \mathrm{~d}^{-1}$, weight-specific growth: $0.03 \mathrm{~d}^{-1}$ ). Growth rate of larvae was positively related to chlorophyll content of water (when $<110 \mathrm{mg} \mathrm{m}^{-2}$ ) and to the available prey biomass. In conclusion, both abundance and growth of larvae were connected to characteristics of the tidal front.
\end{abstract}

\section{INTRODUCTION}

Spawning of North Sea sprat Sprattus sprattus L. takes place during the summer period from March to August, with a main period between late May and July. The major concentrations of sprat larvae are found predominantly in the coastal areas. Aurich (1941) described spawning areas off the English and Danish coasts and in the inner German Bight, but in addition to these areas, large numbers of sprat eggs have been found off the eastern and northern coasts of Scotland (Bailey \& Braes 1976). Spawning intensity in the areas off Scotland has varied markedly during the last decades and, at present, only limited spawning is observed there (McKay 1984). Munk (1991) proposed that the observed changes in relative importance of the major spawning areas have influenced the size compo- sition of recruiting juveniles and thereby the stock structure of North Sea sprat.

Apart from the distribution patterns of eggs and larvae, little is known about the early life of the North Sea sprat. A recent initiative has intensified research on larval sprat in an international cooperation, the Sardine and Anchovy Recruitment Programme (SARP; see Bakun et al. 1991). Several field studies since 1989 have focused on the conditions for sprat larvae in the inner German Bight (e.g. Coombs \& Håkanson 1991, Kloppmann 1991, Valenzuela et al. 1991).

Concentrations of sprat eggs appear to coincide with the distribution of tidal fronts in the North Sea (Munk 1991). This indicates that areas near tidal fronts may offer favourable conditions for the early life of sprat. Consequently, determining the relationship between tidal fronts and sprat larvae has been an 


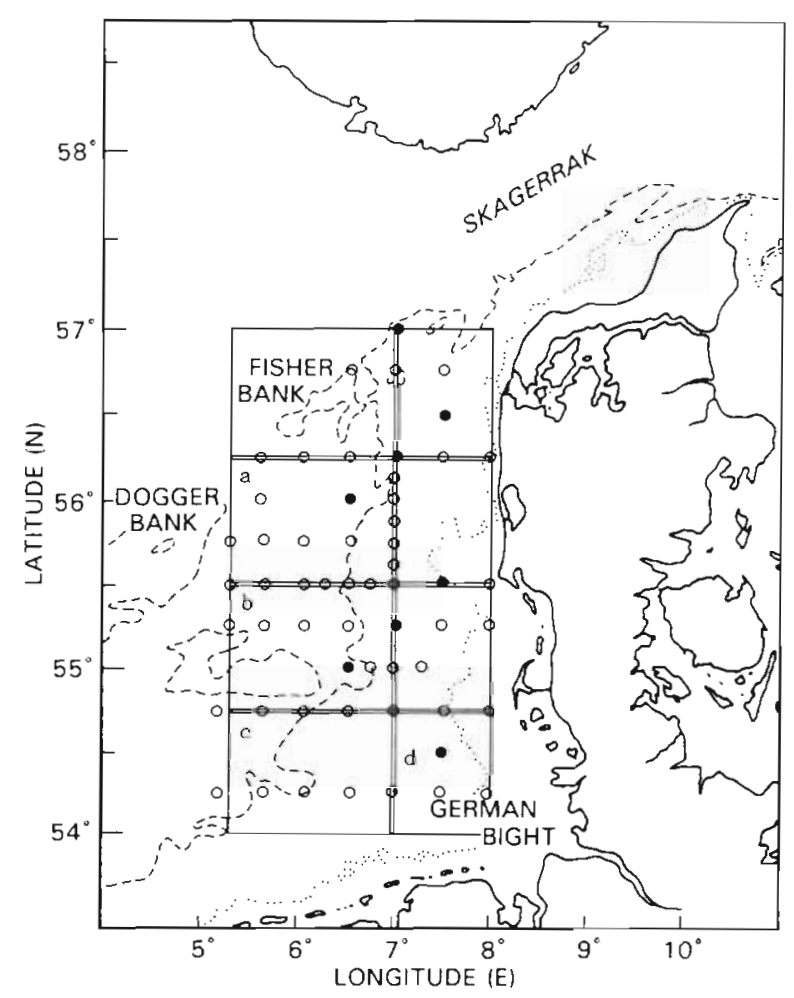

Fig. 1. Eastern North Sea with isolines of bottom depth (20 and $40 \mathrm{~m}$ ). Box encloses study area. Three longitudinal ( $\mathrm{a}, \mathrm{b}$ and $\mathrm{c}$ ) and 1 latitudinal (d) transects are shown by double lines. $(0, \bullet)$ stations; $(\bullet)$ stations where zooplankton were sampled

objective of SARP. The aim of the present study was to evaluate the potential advantage for sprat larvae of residing in the vicinity of a tidal front. An area in the eastern part of the North Sea, off the west coast of Denmark, was chosen for investigation. Basic hypotheses were: (1) the distribution of sprat larvae in the area coincides with the position of a tidal front, and (2) the growth rate of sprat larvae peaks in the frontal zone due to enhanced primary and secondary production in this region.

\section{MATERIALS AND METHODS}

Field studies were carried out from the RV 'Dana' in August 1989. Sampling was performed in a $15^{\prime}$ latitude $\times 30^{\prime}$ longitude station grid, supplemented by additional stations in key areas (Fig. 1). On station a Neil Brown CTD, equipped with a rosette sampler (Hydrobios, 10 bottles of $1.7 \mathrm{l}$ ) and a fluorometer (Qinstruments), was used to profile temperature, salinity and fluorescence at $0.5 \mathrm{~m}$ intervals to $1 \mathrm{~m}$ above the sea bed. Water column stability $\left(\Phi_{1}\right.$ a measure of the work, in $\mathrm{J} \mathrm{m}^{-3}$, required to mix the water column) was calculated (Simpson 1981). Water samples from the flu- orescence maximum and from $3 \mathrm{~m}$ depth were used for determination of phytoplankton productivity (particulate) and chlorophyll a concentration as described in Richardson (1985). Calculation of daily primary production from ${ }^{14} \mathrm{C}$ incorporation is based on the model presented in Richardson \& Christoffersen (1991). Zooplankton was collected by a submersible pump equipped with a $30 \mu \mathrm{m}$ mesh net. Flow rate was $0.5 \mathrm{~m}$ $\mathrm{s}^{-1}$ at the pump opening of $0.1 \mathrm{~m}^{2}$. Samples were integrated in sections of the water column by lowering the pump slowly from the surface to $15 \mathrm{~m}$ and afterwards from $15 \mathrm{~m}$ to the bottom. Zooplankton was preserved in $4 \%$ formalin and later identified to genus Cephalothorax lengths of copepods were measured and their dry weight estimated using separate lengthweight keys (from Kiørboe \& Nielsen 1990).

Ichthyoplankton was sampled at night using a ring net of $3 \mathrm{~m}^{2}$ opening and $1.2 \mathrm{~mm}$ mesh size. A version of this gear is described in Munk (1988). Investigations show that the larger clupeoids, 20 to $40 \mathrm{~mm}$ in length, are capable of only minor gear avoidance at night (unpubl. results). Because of possible extrusion through meshes of the net the catchability of the gear will decline when larval length becomes $<10 \mathrm{~mm}$. Oblique hauls were made to $5 \mathrm{~m}$ above the bottom while the ship cruised at 3 knots. Flow-meter recordings at the net opening were used to estimate the filtered water volume. Samples were preserved in $70 \%$ ethanol, and later all sprat larvae were identified. Because of preservation in ethanol the larvae were wrinkled and nonlinear measurements of larval standard length were made using a microscope with a drawing tube and a digitising board.

From larvae at selected stations, the 2 sagittal otoliths were removed and mounted in a resin (Eukitt) on microscope slides. The otoliths were analyzed using a transmitted light microscope and a video viewing system $(63 \times$ objective, ca $2700 \times$ effective magnification to screen). The maximal diameter of the otolith was measured and the number of dark rings (discontinuity zones) counted starting from the prominent dark ring near the centre (first feeding ring). Two separate counts on each otolith were made and the 4 counts for a larva averaged.

Growth of larvae was estimated using a nonlinear fit (least squares) to the Laird-Gompertz growth equation (exponential growth which decays exponentially; Laird 1969):

$$
L_{t}=L_{0} \exp \{\beta[1-\exp (-\alpha t)]\}
$$

where $L_{t}$ is length $(\mathrm{mm})$ at age $t$ (in days); $L_{0}$ is length $(\mathrm{mm})$ at first feeding; and $\alpha$ and $\beta$ are model parameters.

Length increase at age could be estimated by the derivative of Eq. (1): 
$\mathrm{d} L / \mathrm{d} t=L_{0} \beta \alpha \exp \{\beta[1-\exp (-\alpha t)]-\alpha t\}(2)$

Length increase at a given length is found by solving for age $t$ at this length in Eq. (1) and then inserting $t$ in Eq. (2).

Specific growth rate in weight (SGR) at a given length $L$ is found from:

$$
\mathrm{SGR}_{L}=4.14(\mathrm{~d} L / \mathrm{d} t) / L
$$

where 4.14 is the exponent of the length to weight relationship (for herring; Munk et al. 1991).

The interpolation between samples for contouring of parameter estimates followed a standard procedure. First, a grid finer than the sampling grid was defined and the cell values herein found as the mean (weighted by inverse distance) of the 4 neighbouring sample values ( 1 from each quadrant around the cell). Second, each cell value was recalculated as the average of the given cell and the 8 cells surrounding it. Finally, isolines were drawn between these cells according to their relative magnitude.

\section{RESULTS}

The survey covered the area south of $57^{\circ} \mathrm{N}$ and east of $5^{\circ} \mathrm{E}$ (Fig. 1). A complete coverage of the standard grid was carried out on 11 to 19 August 1989 and supplementary sampling took place on 19 to 24 August 1989. The covered area is shallow to the south and east (Fig. 1). At approximately $40 \mathrm{n}$ miles offshore the water depth approaches $30 \mathrm{~m}$ and, further offshore, depth increases to about $40 \mathrm{~m}$. Between $55^{\circ} 30^{\prime} \mathrm{N}$ and $55^{\circ} 40^{\prime} \mathrm{N}$, a shallow area with water depths below $10 \mathrm{~m}$ extends offshore to $7^{\circ} 20^{\prime} \mathrm{N}$ (the Horns Reef).

\section{Hydrography}

During the survey both thermally stratified and well-mixed water columns were observed. The water column structure is illustrated by cross- and longshore transects in Fig. 2a to d. North of $55^{\circ} 45^{\prime} \mathrm{N}$ a

Fig. 2. Vertical temperature profiles. Isolines are shown in $0.5^{\circ} \mathrm{C}$ steps. Transects along (a) $56^{\circ}$ $15^{\prime} \mathrm{N}$, (b) $55^{\circ} 30^{\prime} \mathrm{N}$, (c) $54^{\circ} 45^{\prime} \mathrm{N}$ and (d) $7^{\circ} \mathrm{E}$
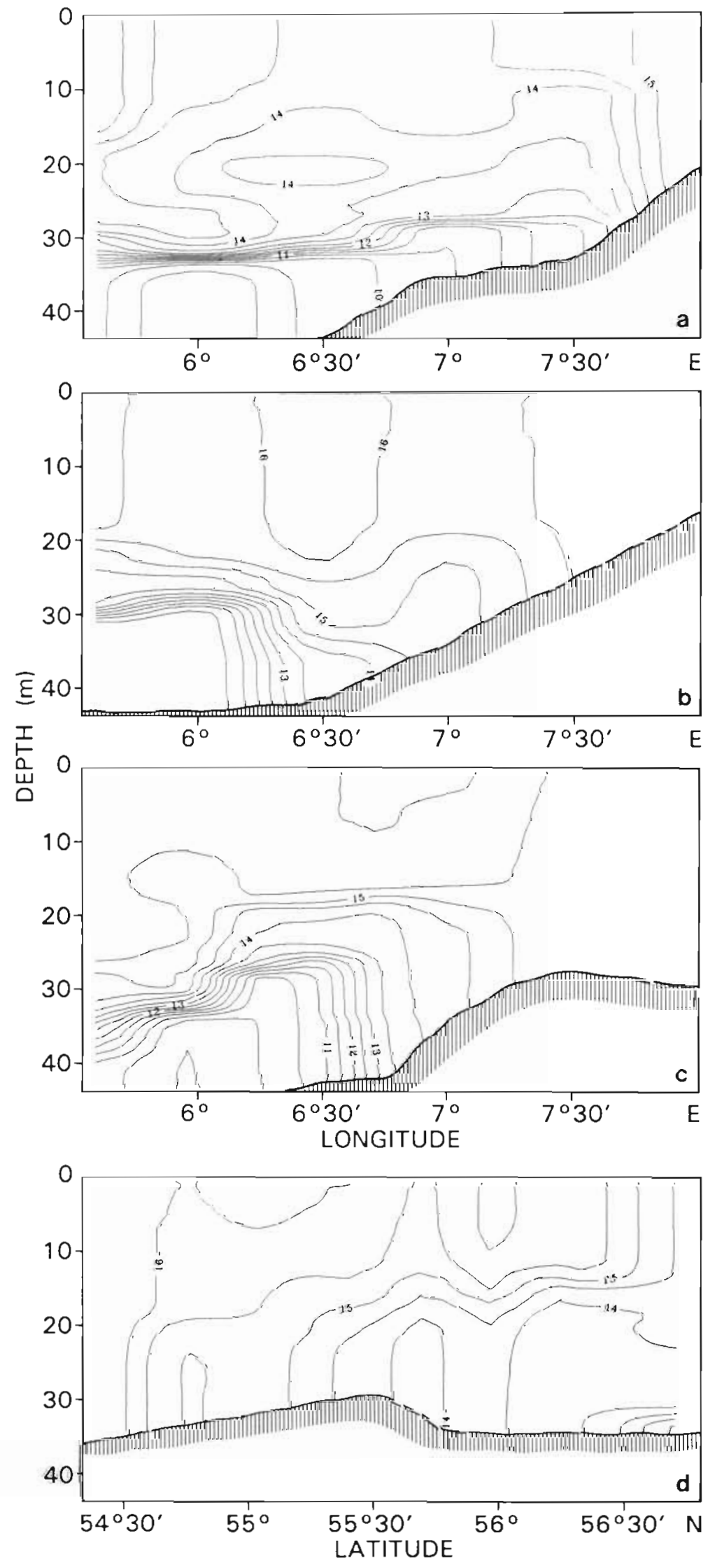


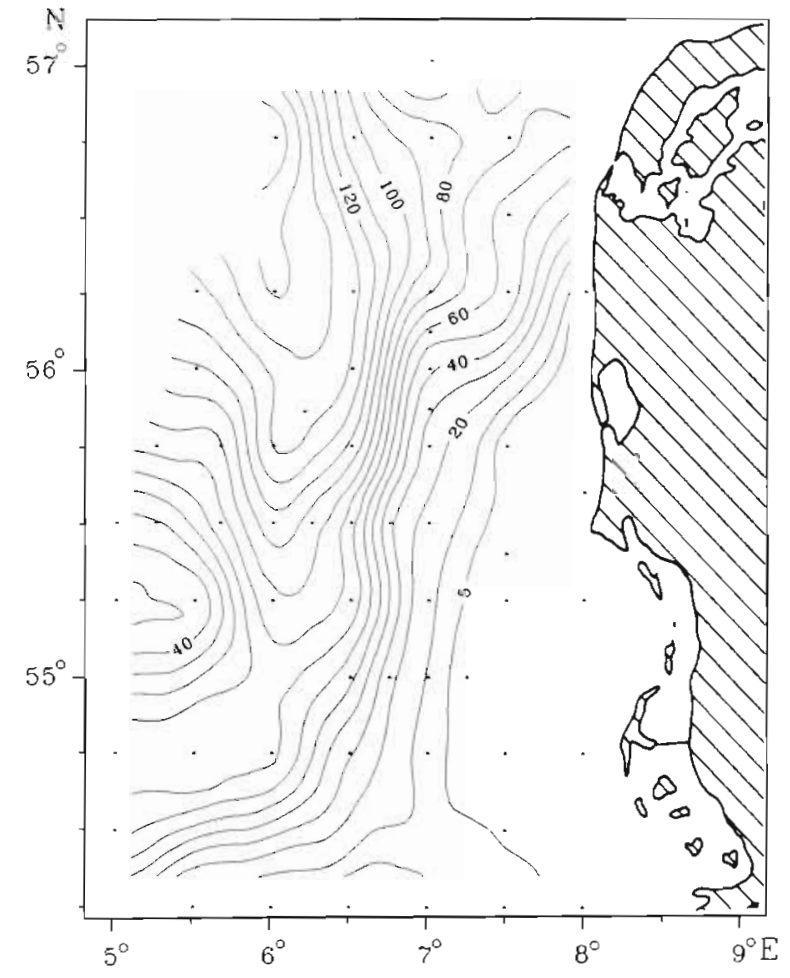

Fig. 3. Stratification of the water column illustrated by stability parameter $\Phi$. Points: measurement positions. Isolines of $5,10,20 \mathrm{~J} \mathrm{~m}^{-3}$ and then every $10 \mathrm{~J} \mathrm{~m}^{-3}$ to $160 \mathrm{~J} \mathrm{~m}^{-3}$

thermocline was found at a depth of approximately $30 \mathrm{~m}$ (Fig. 2a). Here the variation in temperature is paralleled by variation in salinity and a halocline is found at the same depth. South of $55^{\circ} 45^{\prime} \mathrm{N}$ (Fig. $2 \mathrm{~b}$ to c), a thermocline between 20 and $25 \mathrm{~m}$ depth was observed in addition to the thermo/halocline at $30 \mathrm{~m}$ depth. In the northern part of the study area a change from stratified to well-mixed water takes place at the $30 \mathrm{~m}$ depth contour, whereas this change takes place at about $20 \mathrm{~m}$ in the south. Thus, the tidal front is located along the 20 to $30 \mathrm{~m}$ depth contours in the study area. In Fig. 3 , the position of the front is shown by an isopleth of the stability parameter $\Phi$. Stability differences are determined precominantly by temperature differences, and the distribution of surface to bottom temperature differences $(\Delta T)$ shows basically the same pattern. The only exception to this is the relatively low stability in the southwestern part of the area. Thermal stratification is strong here, but a weakening of the haline stratification (by intrusion of relatively saline water, see below) reduces the overall stability.

Surface temperature varies only slightly in the direction perpendicular to the Danish coast, whereas temperature decreases from about 17 to $14.5^{\circ} \mathrm{C}$ longshore from south to north (Fig. 2d). The surface salinity is distributed differently (Fig. 4). South of $55^{\circ} 45^{\prime} \mathrm{N}$, salinity

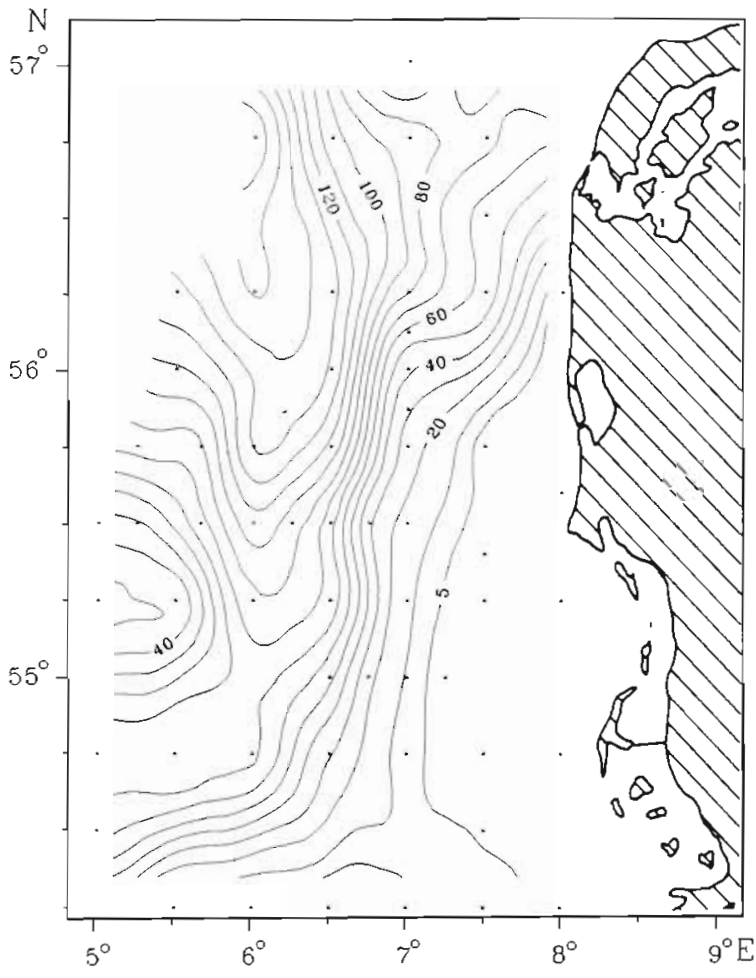

Fig. 4. Surface salinity. Points: measurement positions Isolines given for $32.2 \%$ and every $0.2 \%$ to $34.8 \%$

increases in the offshore direction and relatively high surface salinity is found in the western part here. North of $55^{\circ} 45^{\prime} \mathrm{N}$ the offshore gradient vanishes and a longshore gradient is observed. The observed pattern of surface salinity distribution indicates an interruption of the north-flowing coastal current by intrusion of water from central parts of the North Sea.

\section{Chlorophyll distribution and primary production}

Chlorophyll distribution was related to water column stability but differed between water masses. The water mass north of the intrusion of high salinity water is here distinguished from the central/southern water mass. Stations at or north of $55^{\circ} 45^{\prime} \mathrm{N}$ are 'allocated' to the northern water mass. The vertical fluorescence distribution of the northern water mass was homogenous in mixed water and showed a peak in fluorescence just below the thermocline in stratified water. In the southern water mass the highest fluorescence values were found in the upper part of the water column regardless of its stability. In Fig. 5 the depth-integrated chlorophyll content is illustrated. From relatively high values in mixed water, the chlorophyll content declined offshore. At a given stability of the water column the content differed between the northern and the southern 
water masses. This difference between water masses is significant (covariance test on log-transformed data: $\mathrm{n}=38, \mathrm{p}<0.002$ ).

Phytoplankton production was directly related to its abundance (as estimated by chlorophyll concentration). Production was relatively low $\left(<200 \mathrm{mg} \mathrm{C} \mathrm{m}^{-2}\right.$ $\mathrm{d}^{-1}$ ) in the area north of $55^{\circ} 45^{\prime} \mathrm{N}$, but production increased towards the central parts of the area south of $55^{\circ} 45^{\prime} \mathrm{N}$ where it reached very high values $(>2000 \mathrm{mg}$ C $\left.\mathrm{m}^{-2} \mathrm{~d}^{-1}\right)$.

\section{Zooplankton abundance and distribution}

The positions of the 8 zooplankton samples are shown in Fig. 1. At all stations, 7 genera of calanoid or cyclopoid copepods were represented (see legend for Fig. 6). Echinoderm larvae, bivalve veligers and gastropod veligers were the most abundant noncopepods. Densities of copepods (all stages) ranged between 15 and $32 \mathrm{l}^{-1}$ in the central parts of the study area, whereas between 6 and 13 copepods $1^{-1}$ were found in the periphery.

Oithona sp. dominated numerically at all stations (i.e. constituted between 40 and $80 \%$ by number). Different genera were the second most important: at the 3

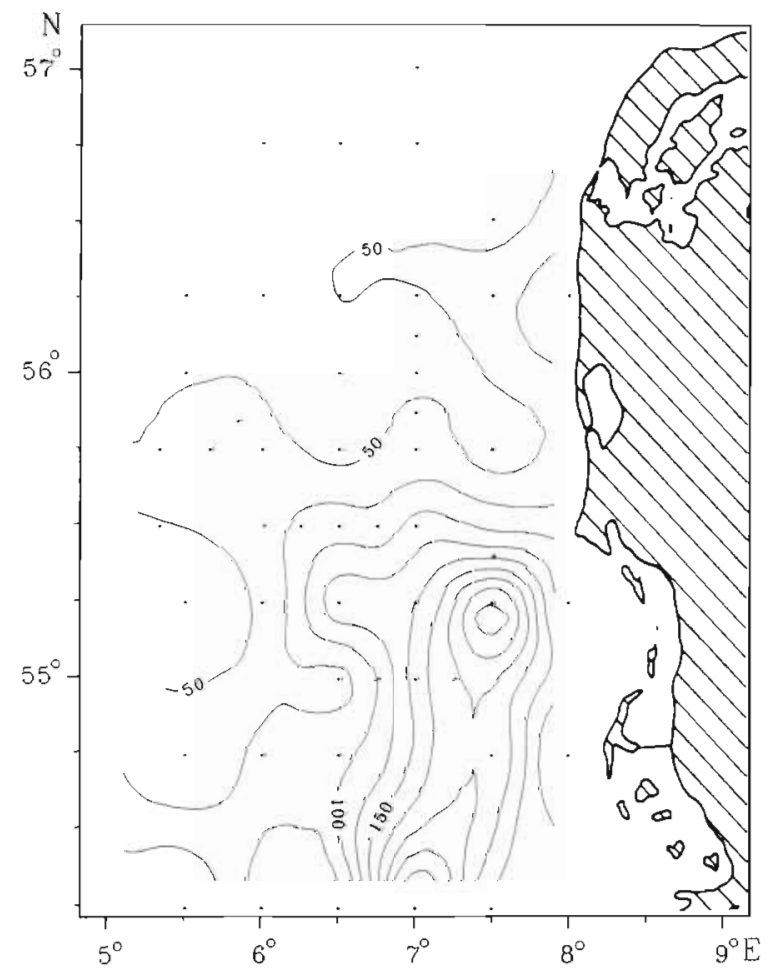

Fig. 5. Depth-integrated chlorophyll a content contoured in the study area. Points: measurement positions. Isolines given for $50 \mathrm{mg} \mathrm{m}^{-2}$ and then every $25 \mathrm{mg} \mathrm{m}^{-2}$ up to $250 \mathrm{mg} \mathrm{m}^{-2}$

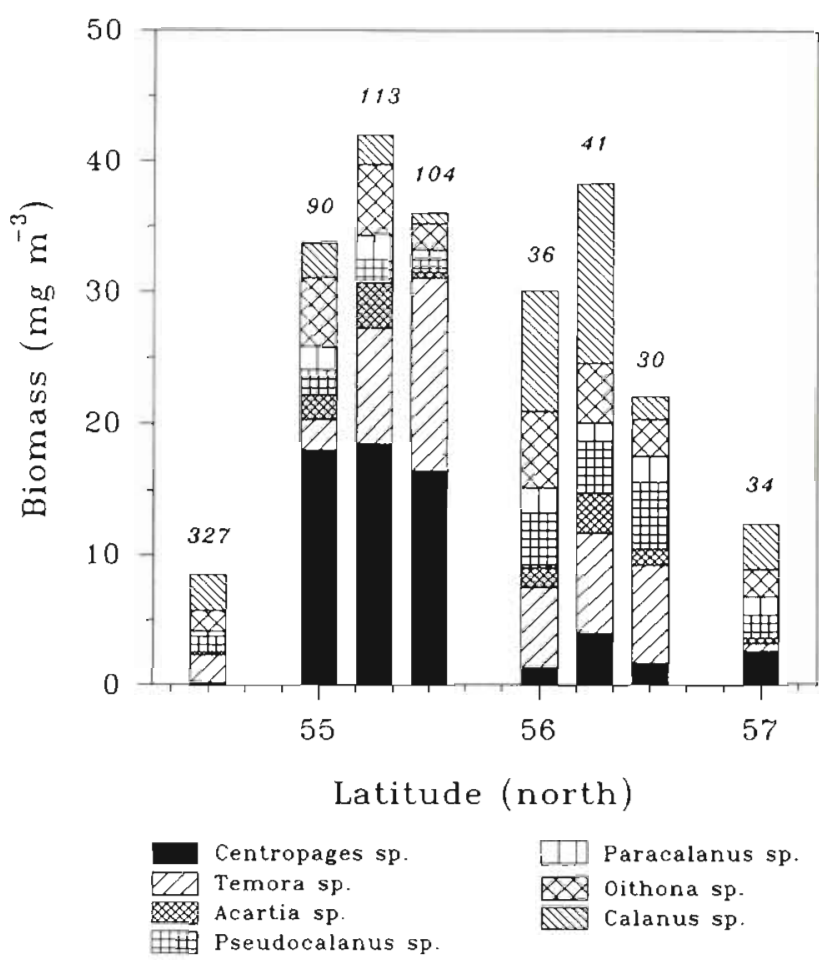

Fig. 6. Biomass density of copepods sampled at positions shown in Fig. 1 Bars illustrate contribution ( $\mathrm{mg}$ dry weight $\mathrm{m}^{-3}$ ) of each of 7 groups of copepods. Values above bars are depthintegrated chlorophyll a $\left(\mathrm{mg} \mathrm{m}^{-2}\right)$ found at same position

stations between $56^{\circ}$ and $56^{\circ} 30^{\prime} \mathrm{N}$, Temora sp. constituted from 21 to $66 \%$ of the number of remaining copepods (minus Oithona sp.), whereas at stations between $55^{\circ}$ and $55^{\circ} 30^{\prime} \mathrm{N}$, Centropages $\mathrm{sp}$. represented from 58 to $73 \%$ of the remainder.

In terms of biomass, Oithona sp. was less important and the biomass of Temora sp., Centropages sp. and Calanus sp. dominated (Fig. 6). Centropages sp. contributed most in the centre-south, while Calanus sp. had a marked influence on total biomass north of $55^{\circ} 45^{\prime} \mathrm{N}$. The southernmost station which had the highest chlorophyll content had the lowest zooplankton biomass of copepods (Fig, 6). When comparing only the remaining stations, the correlation between chlorophyll and copepod biomass is weakly positive, but not significant $(p>0.07, n=7$ ).

\section{Larval abundance and distribution}

Larval sprat were found in samples from all stations. The total number of sprat larvae within the investigated area $\left(46000 \mathrm{~km}^{2}\right)$ is estimated to have been $2.0 \times 10^{10}$. Centres of distribution were found in the southern parts of the study area where densities reached more than $2 \mathrm{~m}^{-2}$ (Fig. 7). Comparison of the distribution of larvae 


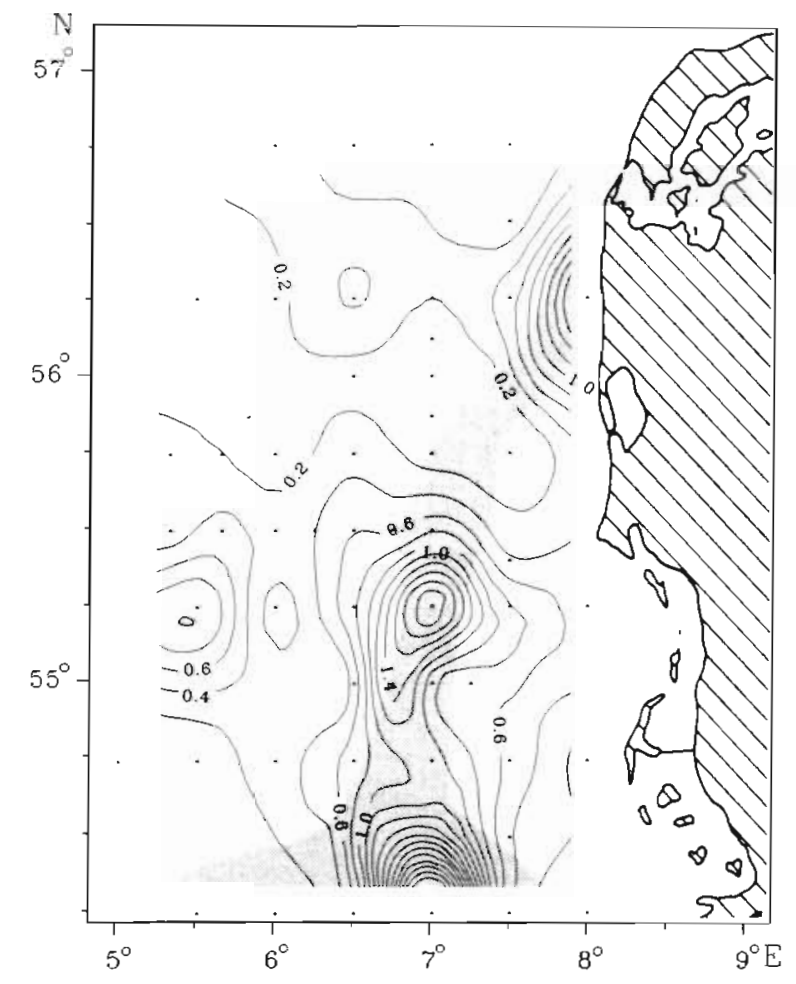

Fig. 7. Sprattus sprattus. Density of larvae contoured in the study area. Points: sampling positions. Isolines given for densities $0.2 \mathrm{~m}^{-2}$ and then every $0.2 \mathrm{~m}^{-2}$ increase to $3.2 \mathrm{~m}^{-2}$. Shaded area: stability $(\Phi)$ between 5 and $30 \mathrm{~J} \mathrm{~m}^{-3}$

and the distribution of water column stability reveals a concurrence between peak densities of larvae and a stability range of 5 to $30 \mathrm{~J} \mathrm{~m}^{-3}$ (shaded area in Fig. 7). For a large part the $60 \mathrm{~J} \mathrm{~m}^{-3}$ contour parallels the 0.6 larvae $\mathrm{m}^{-2}$ contour, and an overwhelming majority of the larvae (>95\%) were found in water masses with stabilities below $60 \mathrm{~J} \mathrm{~m}^{-3}$.

\section{Larval size and age}

Sprat larvae ranged from 5 to $27 \mathrm{~mm}$ in length (standard length of preserved specimens). At many stations, significant polymodality in length was observed ( 2 or 3 modes). Modes of 12 and $16 \mathrm{~mm}$ lengths dominated. Subgroups of larvae could, in some instances, be traced from station to station by their mode of length distribution. However, the present data are not sufficiently detailed to allow a separation of the very intermixed groups. In Fig. 8, the spatial distribution of larval size categories is illustrated by the mean length only. A number of local minima in length of larvae were found. In only 1 case did such a minimum coincide with a local maximum of larval abundance. Mean larval length increased

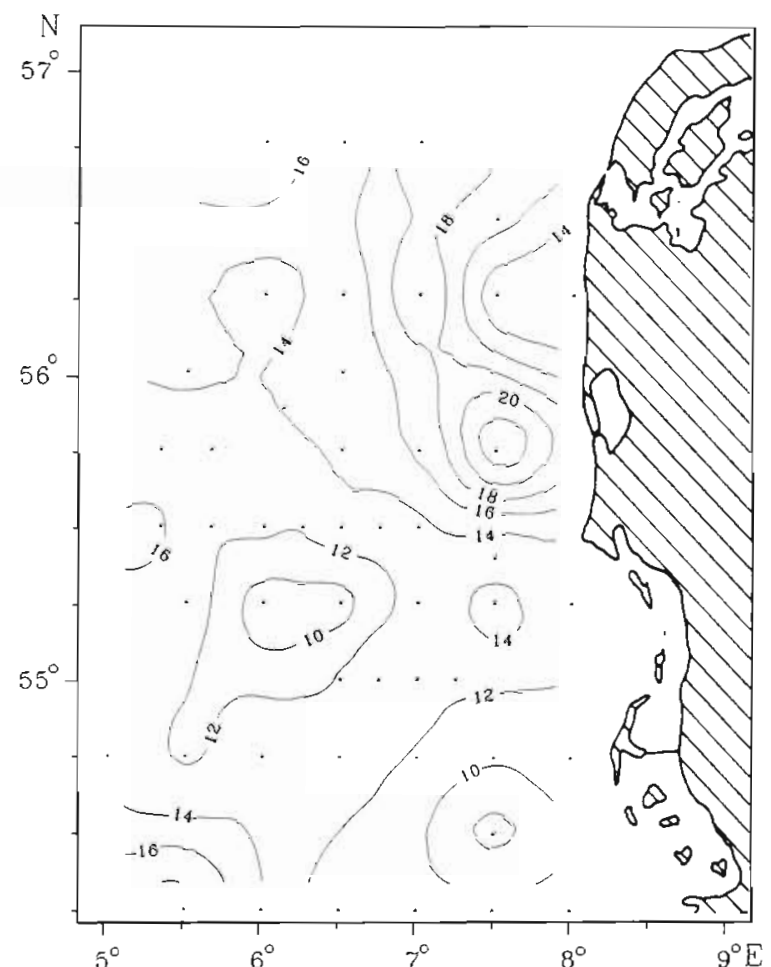

Fig. 8. Sprattus sprattus. Mean length of larvae, contoured in study area. Points: sampling positions. Isolines given for $8 \mathrm{~mm}$ standard length, and then every $2 \mathrm{~mm}$ increase to $22 \mathrm{~mm}$

gradually in a northerly and westerly direction. In the northeastern part of the study area patches of smaller larvae were separated by a distribution of large larvae (mean length $>18 \mathrm{~mm}$ ).

Larval age was estimated from increments on the sagittal otolith. Shields (1989) validated the correspondence between number of increments and age in days of sprat larvae. He found a one-to-one relationship when increment widths were $>1.5 \mu \mathrm{m}$. In the present study increments were $>1.5 \mu \mathrm{m}$, thus their number is assumed to reflect age in days. In total 1345 pairs of sagitta were analyzed. Estimated ages ranged from 2 to $75 \mathrm{~d}$. Of the age distribution of all analyzed larvae, modes of ages 15 and $25 \mathrm{~d}$ were dominant, corresponding to the modes of 12 and $16 \mathrm{~mm}$ from the length distribution.

\section{Growth of larvae}

Larval growth was estimated by a regression of length against age, thus assuming that the growth histories of larvae in a given sample were the same (see examples in Fig. 9a). The measured length of individual larvae was, however, affected by a variation in 

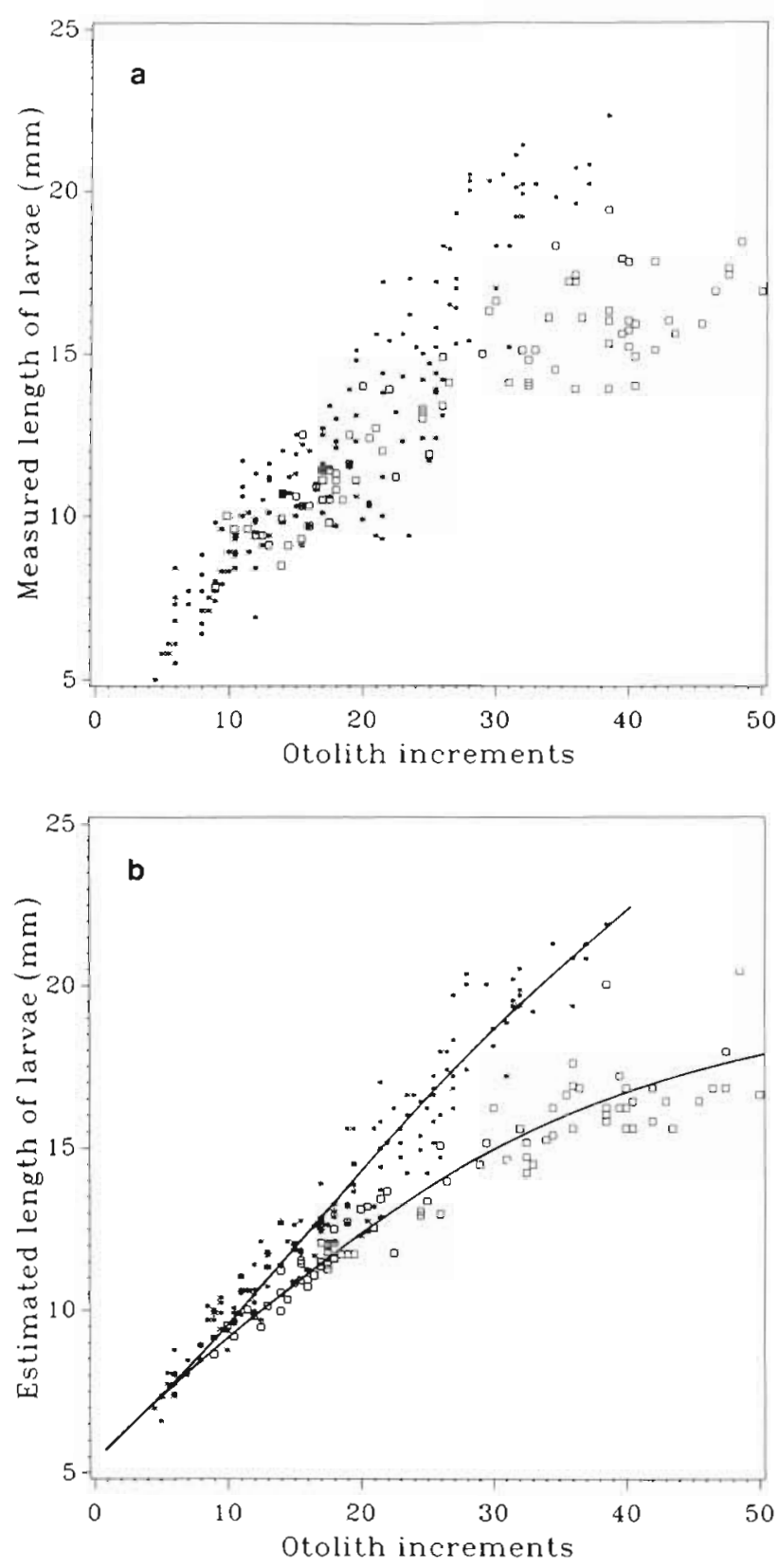

Fig. 9. Sprattus sprattus. Growth curves. (a) Measured standard length of larvae versus otolith increments for 2 data subsets. (*) Relationship for fast-growing specimens; ( $\square$ ) slowgrowing ones. Fit of Laird-Gompert $z$ growth curves reveals in both cases $r^{2}$ of 0.86 ( $n=164$ and $n=87$ respectively). (b). Estimated standard length of larvae (based on otolith sizes) versus otolith increments. Same data sets as for (a). Lines show fit of Laird-Gompertz curves, $\mathrm{I}^{2}$ for the fast growers is 0.94 $(n=164)$ and for the slow growers $0.91(n=87)$

shrinkage and by an imprecision of the length measurement due to the wrinkled bodies. Hence, an attempt was made to improve regressions by use of otolith sizes as estimators of individual body lengths. Sagittal otoliths are unlikely to shrink (Leak 1986), and their shape allows for linear measurements. But, an unambiguous relationship between otolith sizes (maximal diameter) and larval lengths is a prerequisite. The relationship was estimated as: larval standard length $(\mathrm{mm})=1.45[\mathrm{max} \text {. diameter }(\mu \mathrm{m})]^{0.49}$, in a linear regression of log-transformed data $\left(r^{2}=0.87, n=1307\right)$. No systematic trend in residuals of length estimates was observed.

A decoupling of the relationship between larval and otolith size is, however, possible (Mosegaard et al. 1988, Secor \& Dean 1989). This decoupling has been related to growth rate differences; a slowly growing larva may have relatively larger otoliths than a faster growing larva. This potential effect was tested in the present material by comparing larvae from 2 stations where lengths at age were largest with 2 stations where lengths at age were shortest (Fig. 9a). Regressions of log(length) against log(otolith diameter) were not significantly different between subsets of data (covariance test; $n=250, p>0.11$ ), and the effect is assumed to be negligible.

Thus, lengths estimated from otolith sizes were used when fitting data to the Laird-Gompertz equation (Eq. 1). Size at first feeding was set to the mean size of larvae where only the prominent (first feeding) ring on

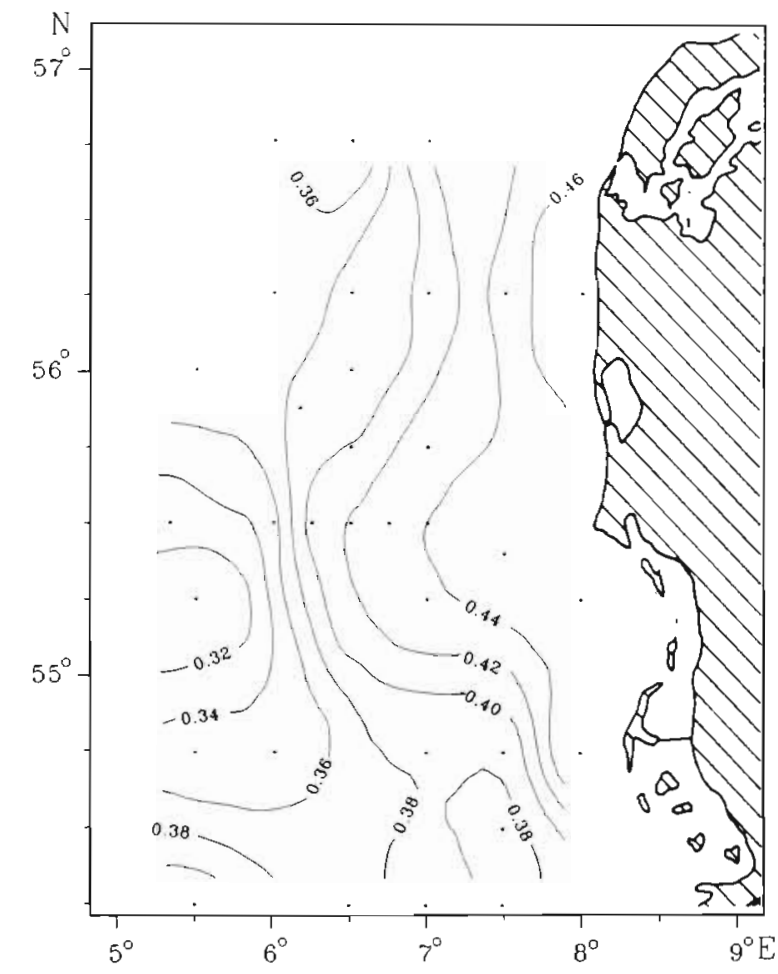

Fig. 10. Sprattus sprattus. Growth estimates of $12 \mathrm{~mm}$ larvae $\left(\mathrm{mm} \mathrm{d}^{-1}\right)$ in the study area. Points: sampling positions for otolith analysis. Isolines given for length increase of $0.32 \mathrm{~mm}$ $\mathrm{d}^{-1}$ and every $0.2 \mathrm{~mm} \mathrm{~d}^{-1}$ to $0.46 \mathrm{~mm} \mathrm{~d}^{-1}$ 
otoliths was visible $(5.3 \mathrm{~mm})$. In all regressions the coefficients of determination $\left(r^{2}\right)$ improved when using estimated lengths instead of measured lengths (compare the examples given in Fig. 9a, b). Growth rates of 12 and $16 \mathrm{~mm}$ larvae were subsequently found using the parameter estimates and Eq. (2). Illustration of growth rates for these 2 length groups were chosen because of their prevalence in the material.

In Fig. 10 the variation in growth of $12 \mathrm{~mm}$ larvae is given for the entire area and in Fig. 11 growth rate estimates of (a) 12 and (b) $16 \mathrm{~mm}$ larvae are plotted for each of the 3 transects shown in Fig. 2a to c as a func-
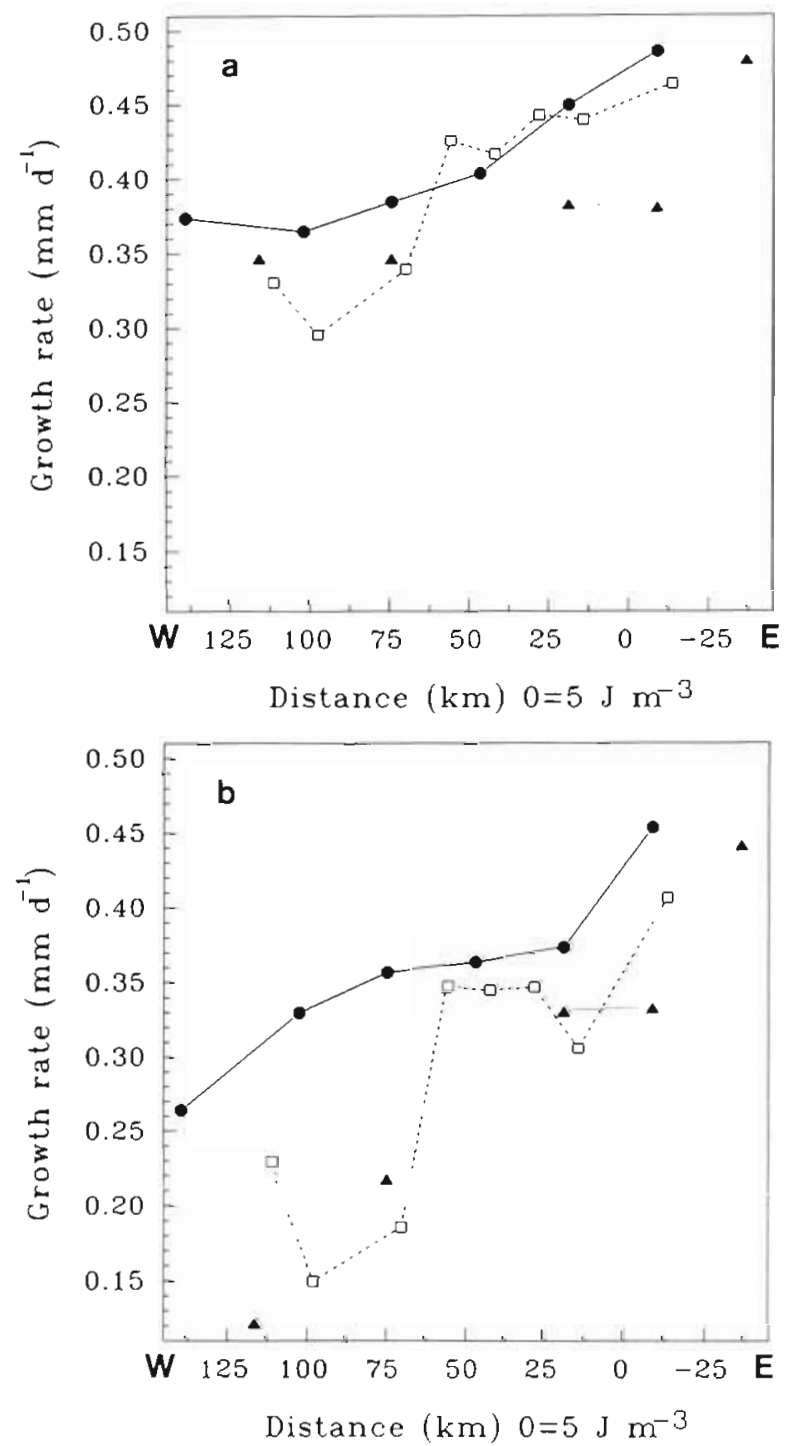

Fig. 11. Sprattus sprattus. Growth estimates of larvae (mm $\mathrm{d}^{-1}$ ) along longitudinal transects (east and west indicated). Distance across front is measured with reference to inshore side of front $\left(\Phi=5 \mathrm{~J} \mathrm{~m}^{-3}\right)$. (a) Growth of $12 \mathrm{~mm}$ larvae along $56^{\circ} 15^{\prime} \mathrm{N}(\bullet), 55^{\circ} 30^{\prime} \mathrm{N}\left(\right.$ (a) and $54^{\circ} 45^{\prime} \mathrm{N}(\Delta)$. (b) Growth of $16 \mathrm{~mm}$ larvae along same transects as for (a)

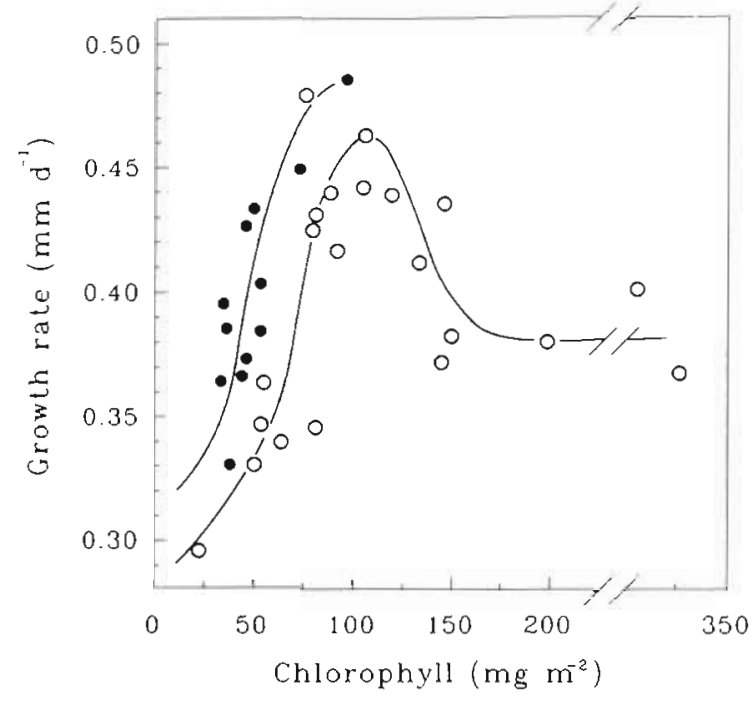

Fig. 12. Sprattus sprattus. Growth rates of $12 \mathrm{~mm}$ larvae $(\mathrm{mm}$ $\left.\mathrm{d}^{-1}\right)$ in relation to integrated chlorophyll a content $\left(\mathrm{mg} \mathrm{m}^{-2}\right)$ at sampling position. (•) Sampling north of $55^{\circ} 45^{\prime} \mathrm{N}_{i}(0)$ sampling south of $55^{\circ} 45^{\prime} \mathrm{N}$. Fitted curves are shown for sampling either north or south of $55^{\circ} 45^{\prime} \mathrm{N}$

tion of the distance to the front (here set to the $\Phi=5 \mathrm{~J}$ $\mathrm{m}^{-3}$ isoline). Growth rates tend to decline in the offshore (westward) direction. They were high on the mixed side of the front, about $0.47 \mathrm{~mm} \mathrm{~d}^{-1}$ for the $12 \mathrm{~mm}$ larvae, corresponding to a specific growth rate in weight (SGR, Eq. 3) of $0.16 \mathrm{~d}^{-1}$, and about $0.43 \mathrm{~mm}$ $\mathrm{d}^{-1}$ (SGR $0.11 \mathrm{~d}^{-1}$ ) at $16 \mathrm{~mm}$ length. At the westernmost sampling sites, these rates were reduced to between 0.13 and $0.35 \mathrm{~mm} \mathrm{~d}^{-1}$ (SGR between 0.03 and $0.12 \mathrm{~d}^{-1}$ ). South of $55^{\circ} 45^{\prime} \mathrm{N}$ the offshore decline in growth rate was more pronounced in the case of the 16 $\mathrm{mm}$ than of the $12 \mathrm{~mm}$ larvae. Accordingly, the parameter $\alpha$ in Eq. (1) which describes the decay in growth rate with larval length increased significantly in the offshore direction south of $55^{\circ} 45^{\prime}(\mathrm{n}=24, \mathrm{p}<0.008)$.

\section{Larval growth in relation to environmental parameters}

Growth rate and stability were inversely related in the area east of $6^{\circ} \mathrm{E}$. However, in the westernmost parts of the study area low values of both stability and growth rate were observed. Thus growth rate showed no unambiguous relation to stability. The relationship between growth estimates of $12 \mathrm{~mm}$ larvae and the chlorophyll content of the water column is shown in Fig. 12. Growth rates were apparently linearly related to chlorophyll content up to $90 \mathrm{mg} \mathrm{m}^{-2}$ and south of $55^{\circ} 45^{\prime} \mathrm{N}$ they diminished at contents exceeding $110 \mathrm{mg} \mathrm{m}^{-2}$. There is an apparent difference in the first 
part of this relationship between areas north and south of $55^{\circ} 45^{\prime} \mathrm{N}$. A covariance test analyzing the combined effect of site, chlorophyll and temperature (at surface or at thermocline) was applied to growth of $12 \mathrm{~mm}$ larvae. The effect of temperature, both at the surface and the thermocline, was insignificant. In a test with site and chlorophyll only, both factors were significant at $\mathrm{p}<0.05$ and $\mathrm{p}<0.001$ respectively $(\mathrm{n}=29)$.

The influence of primary production on larval growth rate is mediated through its effect on secondary production and zooplankton abundance. In this context it is not so much the total zooplankton biomass, but the size fraction that larvae are capable of eating that is important. The available biomass of copepods, the predominant prey item of sprat larvae (Conway et al. 1991), is estimated using the information gained for another clupeoid, the herring (Munk 1992). Based on the relative preferences for copepods in logarithmic length intervals of herring larvae $12 \mathrm{~mm}$ in length (Munk 1992), indices of prey availability were calculated (the higher the preference the higher the availability). Indices for $12 \mathrm{~mm}$ larvae were calculated for each station of concurrent sampling of larvae and zooplankton. Comparison revealed a significant positive correlation $\left(p<0.03, n=8, r^{2}=0.59\right)$.

\section{DISCUSSION}

The results of this study support the hypothesis that the distribution of sprat larvae coincides with the zone of a tidal front. A minor part of the larvae were found in the strongly stratified and completely mixed water masses, whereas centres of distributions (both of younger and older larvae) were found at the immediate mixed side of the frontal zone - at water column stabilities of 5 to $30 \mathrm{~J} \mathrm{~m}^{-3}$. Because of the proximity of the Dogger Bank, the isolines of water column stability diverge into a zone associated with the southern part of the Bank and one extending towards the German Bight. Likewise the distribution of larvae diverges into a minor part extending to the southern areas of the Dogger Bank and a major part that extends towards the German Bight.

The distribution of sprat larvae on the Dogger Bank was investigated in August 1991 (Munk unpubl.). Large numbers of larvae were found associated with a tidal front there. The larvae in the southwestern region of the present study area are probably an extension of larval patches at the Bank. Valenzuela et al. (1991) studied the distribution and ecology of sprat larvae in the German Bight in June 1989. In their area of study, south of $54^{\circ} 06^{\prime} \mathrm{N}$ and east of $7^{\circ} 53^{\prime} \mathrm{E}, 2$ frontal systems were observed, a tidal mixing front and a river plume front. At a transect cutting through the tidal mixing front the authors found maximal densities of sprat larvae at the stations closest to the coast. From their presentation of the hydrography along the transect, these stations appear positioned at the innermost side of the tidal front, still with a weak stratification of the water column. Hence, their findings are in accordance with the present observations

The possible drift routes of sprat larvae in 1989 have been studied by Bartsch (1991). Hydrographic modelling based on meteorological fields indicated that the current circulation pattern in the North Sea was anomalous in the summer period of 1989. During this year larvae were less apt to drift northwards than in a 'normal' year. Modelled drift of passive tracers at $5 \mathrm{~m}$ depth, released at a presumed spawning ground in the western part of the German Bight, showed little dispersion of larvae away from the area of release (Bartsch 1991). The present observations of distributions are not in accordance with the predictions of the model, since significant numbers of larvae were found as far north as $56^{\circ} \mathrm{N}$. The discrepancy could stem from an erroneous restricted area of release in the model while observations of egg dispersal during April-June 1989 show significant spawning up to $56^{\circ} \mathrm{N}$ (van der Land 1990).

The hypothesis that growth of larvae is especially promoted in the frontal zone was not unconditionally supported in the present study because growth rates peaked in the mixed water masses. However, there was only a slight decline in growth rate estimates from mixed to frontal water, where larval abundances were highest. Towards the more stratified water columns, growth rate declined significantly. Growth rates were positively correlated to primary production (chlorophyll content), except at very high levels of chlorophyll where the growth rate may be depressed. The stations with very high levels of chlorophyll, concurrent with a low abundance of zooplankton, are situated in mixed water. Thus, examples of suboptimal conditions in mixed water were found.

The present findings show that both the spatial distribution and growth of sprat larvae are closely connected to hydrography. Dispersal of sprat larvae is to a large extent bounded by a tidal front, and the restriction of their spatial distribution centres to the inshore side of the frontal zone is apparently profitable with respect to growth. The retention of larvae in areas of tidal fronts has been described in a number of studies (e.g. herring: Kiørboe et al. 1988, Chenoweth et al. 1989, Fortier \& Gagné 1990; cod: Suthers et al. 1989), and the profitability of retention areas to larval growth and survival has been much debated. Based on the findings of herring larval distributions, a hypothesis of 'larval retention' was proposed by Iles \& Sinclair (1982). Originally the hypothesis deait with the dis- 
tinctness of herring stocks, the stocks being determined by the extent of distinct, geographically stable retention areas. Later Sinclair \& Iles (1985) argued that, since these areas are often suboptimal as nursery areas, larvae are distributed in these regions in spite of and not because of the food resources there. Frank (1988) rejected this statement on the basis of a reevaluation of food resource estimates from a number of studies, including the one used by Sinclair \& Iles (1985).

Actually, many cases of co-occurrence of larvae and their prey have been described (e.g. Townsend et al. 1986, Kiørboe et al. 1988, Chenoweth et al. 1989), and as in the present study, Suthers et al. (1989) showed an improved growth ability of cod larvae within the area of retention. The present findings point to the importance of a match between distribution of larvae and areas/periods that offers superior conditions for larval life, thus supporting the match/mismatch theory (Hjort 1926, Cushing 1972).

Acknowledgements. I sincerely thank the many persons involved in the collection and treatment of samples, including the officers and crew of RV 'Dana'. Thanks also to colleagues and referees for constructive reviews of the manuscript.

\section{LITERATURE CITED}

Aurich, H. J. (1941). Die Verbreitung der pelagischen Fischbrut in der südlichen Nordsee während der Frühjahrsfahrten 1926-1937 der deutschen Forschungsschiffe 'Poseidon' und 'Makrele'. Helgoländer wiss. Meeresunters. 2(2): $184-225$

Bailey, R. S., Braes, A. (1976). Surveys of sprat eggs and larvae to the north and east of Scotland 1973-75. Comm. Meet. Int. Coun. Explor. Sea, C.M.-ICES 1975/H: 13

Bakun, A., Alheit, A., Kullenberg, G. (1991). The sardineanchovy recruitment project (SARP): rationale, design and development. Comm. Meet. Int. Coun. Explor. Sea C.M.ICES 1991/L: 43

Bartsch, J (1991). Modelling the transport of herring and sprat larvae in the North Sea. Comm. Meet. Int. Coun. Explor. Sea C.M.-ICES 1991/L: 7

Chenoweth, S. B., Libby, D. A., Stephenson, R. L., Power, M. J. (1989). Origin and dispersion of larval herring (Clupea harengus) in coastal waters of eastern Maine and southwestern New Brunswick. Can. J. Fish. Aquat. Sci. 46: $624-632$

Conway, D. V. P., Tranter, P. R. G., Fernandez de Puelles, M. L., Coombs, S. H. (1991). Feeding of larval sprat (Sprattus sprattus L.) and sardine (Sardina pilchardus Walbaum). Comm. Meet. Int. Coun. Explor. Sea C.M.ICES/L: 76

Coombs, S. H., Håkanson, J. L. (1991). Diel variation in lipid and elemental composition in sprat (Sprattus sprattus L.) larvae at mixed and stratified sites in the German Bight of the North Sea. Int. Coun. Explor. Sea, C.M.-ICES 1991/L: 49

Cushing, D. H. (1972). The production cycle and the number of marine fish. Symp. zool. Soc. Lond. 29: 213-232

Fortier, L., Gagné, J. A. (1990). Larval herring (Clupea haren- gus) dispersion, growth and survival in the St. Lawrence Estuary: match/mismatch or membership/vagrancy? Can. J. Fish. Aquat. Sci. 47: 1898-1912

Frank, K. T. (1988). Independent distributions of fish larvae and their prey: natural paradox or sampling artifact? Can. J. Fish. Aquat. Sci. 45: 48-59

Hjort, J. (1926). Fluctuations in the year classes of important food fishes. J. Cons. perm. int. Explor. Mer 1: 5-38

Iles, T. D., Sinclair, M. (1982). Atlantic herring: stock discreteness and abundance. Science 215: 627-633

Kiørboe, T., Munk, P., Richardson, K., Christensen, V., Paulsen, H. (1988). Plankton dynamics and larval herring growth, drift and survival in a frontal area. Mar. Ecol. Prog. Ser. 44: 205-219

Kiørboe, T., Nielsen, T. G. (1990). Effects of wind stress on vertical column structure, phytoplankton growth, and productivity of planktonic copepods. In: Barnes, M., Gibson, R. N. (eds.). Trophic relationships in the marine environment. Aberdeen University Press, Aberdeen, p. 28-40

Kloppmann, M. (1991). Vertical distribution of sprat larvae in the German Bight. Comm. Meet. Int. Coun. Explor. Sea C.M.ICES 1991/L: 26

Laird, A. K. (1969). The dynamics of growth. Res./Dev. 20(8): $28-31$

Leak, J. C. (1986). The relationship of standard length and otolith diameter in larval bay anchovy, Anchoa mitchilly (Val.). A shrinkage estimator. J. exp. mar. Biol. Ecol. 95 $167-172$

McKay, D. W. (1984). Sprat larvae off the east coast of Scotland. Cornm. Meet. Int. Coun. Explor. Sea C.M.-ICES 1984/H: 56

Mosegaard, H., Svedäng, H., Taberman, K. (1988). Uncoupling of somatic and otolith growth rates in arctic char (Salvelinus alpinus) as an effect of differences in temperature response. Can. J. Fish. Aquat. Sci. 45: $1514-1524$

Munk, P. (1988). Catching large herring larvae: gear applicability and larval distribution. J. Cons. int. Explor. Mer, 45: 97-104

Munk, P. (1991). Changes in mean size and distribution of juvenile North Sea sprat (Sprattus sprattus L.) in the period 1976-90. Comm. Meet. Int. Coun. Explor. Sea C.M.-ICES 1991/L: 43

Munk, P. (1992). Foraging behaviour and prey size spectra of larval herring Clupea harengus. Mar. Ecol. Prog. Ser. 80: $149-152$

Munk, P., Heath, M., Skaarup, B. (1991). Regional and seasonal differences in growth of larval North Sea herring (Clupea harengus L.) estimated by otolith microstructure analysis. Cont. Shelf. Res. 11(7): 641-654

Richardson, K. (1985). Plankton distribution and activity in the North Sea/Skagerrak-Kattegat frontal area in April 1984. Mar. Ecol. Prog. Ser. 26: 233-244

Richardson, K., Christoffersen, A. (1991). Seasonal distribution and production of phytoplankton in the southern Kattegat. Mar. Ecol. Prog. Ser. 78: 217-227

Secor, D. H., Dean, J. M. (1989). Somatic growth effects on the otolith - fish size relationship in young pond-reared striped bass, Morone saxatilis. Can. J. Fish. Aquat. Sci. 46: $113-121$

Shields, R. J. (1989). Studies of growth and nutritional status in O-group sprat, Sprattus sprattus (Clupeida), using otolith microstructure and lipid analyticaltechniques. Ph.D. Thesis. University of Wales, Bangor

Simpson, J. H. (1981). The shelf sea fronts: implications of their existence and their behaviour. Phil. Trans. R. Soc. 302(A): 531-546 
Sinclair, M., Iles, T. D. (1985). Atlantic herring (Clupea harengus) distributions in the Gulf of Maine-Scotian Shelf area in relation to oceanographic features. Can. J. Fish. Aquat. Sci $42: 880-887$

Suthers, I. M., Frank K. T., Campana S. E. (1989). Spatial comparison of recent growth in postlarval Atlantic cod (Gadus morhua) off southwestern Nova Scotia: inferior growth in a presumed nursery area. Can. J. Fish. Aquat. Sci. 46 (Suppl. 1): 113-124

Townsend, D. W., Graham, J. J., Stevenson, D. K. (1986). Dynamics of larval herring (Clupea harengus L.) production in tidally mixed waters of the eastern coastal Gulf of

This article was submitted to the editor
Maine, In: Bowman, J. J., Yentsch, C. M., Peterson, W. T. (eds.) Tidal mixing and plankton dynamics. Springer Verlag, Berlin, p. 253-277

Valenzuela, G., Alheit, J., Coombs, S. H., Knust, R. (1991). Spawning patterns of sprat and survival changes of sprat larvae in relation to frontal systems in the German Bight. Comm. Meet. Int. Coun. Explor. Sea C.M.-ICES 1991/L: 45

van der Land, M. A. (1990). Distriubution and mortality of pelagic eggs of by-catch species in the 1989 egg surveys in the southern North Sea. Comm Meet. Int. Coun. Explor. Sea. C.M.-ICES 1990/H: 19

Manuscript first received: February 16, 1993

Revised version accepted: June 2, 1993 